\title{
INFORMATION TECHNOLOGY OF CLIMATE MONITORING
}

Talakh M. V. - PhD, Assistant Professor of Department of Computer Science, Yuriy Fedkovych Chernivtsi National University, Chernivtsi, Ukraine.

Holub S. V. - Dr. Sc., Professor of Department of Automated Systems Software, Cherkasy State Technological University, Cherkasy, Ukraine.

Turkin I. B. - Dr. Sc., Professor, Head of Department of Software Engineering, National Aerospace University "Kharkiv Aviation Institute", Kharkiv, Ukraine.

\begin{abstract}
Context. Information monitoring technology is used to reduce information uncertainty about the regularity of air temperature changes during managing work in hard-to-reach places [1]. The task was to create a method for modelling one of the climatic indicators, air temperature, in the given territories in the information monitoring technology structure. Climate models are the main tools for studying the response of the ecological system to external and internal influences. The problem of reducing information uncertainty in making managerial decisions is eliminated by predicting the consequences of using planned control actions using climate modelling methods in information monitoring technology. The information technology of climate monitoring combines satellite observation methods and observations on climate stations, taking into account the spatial and temporal characteristics, to form an array of input data. It was made with the methods for synthesizing models of monitoring information systems [1] and methods of forming multilevel model structures of the monitoring information systems [1] for converting observation results into knowledge, and with the rules for interpreting obtained results for calculating the temperature value in the uncontrolled territories.

Objective of the work is to solve the problem of identifying the functional dependence of the air temperature in a given uncontrolled territory on the results of observations of the climate characteristics by meteorological stations in the information technology of climate monitoring structure.

Method. The methodology for creating information technologies for monitoring has been improved to expand its capabilities to perform new tasks of forecasting temperature using data from thermal imaging satellites and weather stations by using a new method of climate modelling. A systematic approach to the process of climate modelling and the group method of data handling were used for solving problems of functional dependence identification, methods of mathematical statistics for evaluating models.

Results. The deviation of the calculated temperature values with the synthesized monitoring information systems models from the actual values obtained from the results of observations by artificial earth satellites does not, on average, exceed $2.5^{\circ} \mathrm{C}$. Temperature traces obtained from satellite images and weather stations at similar points show similar dynamics.

Conclusions. The problem of the functional dependence identification of air temperature in uncontrolled territories on the results of observations at meteorological stations is solved. The obtained results were used in the process of creating a new method of climate modelling within information technology of climate monitoring. Experimental confirmation of the hypothesis about the possibility of using satellite images in regional models of temperature prediction has been obtained. The effectiveness of the application of the methodology for the creation of monitoring information technologies during the implementation of the tasks of reducing uncertainty for management decisions during works in non-controlled territories has been proven.
\end{abstract}

KEYWORDS: information technology, monitoring, climate models, observations, air temperature, thermal imagery, Landsat satellites, inductive modelling, machine learning.

\footnotetext{
ABBREVIATIONS

GMDH is a group method of data handling;

MIS is a monitoring information systems;

RT is a real temperature;

$\mathrm{PT}$ is a predicted temperature;

AP is an absolute error;

$\mathrm{MinV}$ is a min value;

$\mathrm{MaxV}$ is a max value;

DFC is a direction of function's change;

$\mathrm{SV}$ is a variable name, showing reliable changing of function's value;

IMT is an information monitoring technology;

ITCM is an information technology of climate monitor-

MIS is a monitoring information systems;

AID is an array of input data;

OLAP is an online analytical processing.
} ing;

\section{NOMENCLATURE}

$Y$ is a set of the dependent variables;

$X$ is an independent variable;

DOI 10.15588/1607-3274-2021-2-16

$m$ is a number of temperature observation points;

$n$ is a number of features obtained from the results of observations at meteorological stations;

$L_{\lambda}$ is a spectral density of the radiant luminosity at the sensor aperture, that is, the power of the energy flux (Watt) per $\mathrm{m}^{2}$ of the earth's surface per steradian;

$Q_{c a l}$ is a pixel value;

$Q_{\text {Cal }_{\min }}$ is a minimum pixel value, which corresponds to $L_{\min _{\lambda}}$;

$Q_{c a l_{\max }}$ is a maximum pixel value, which corresponds to $L_{\max _{\lambda}}$;

$L_{\min _{\lambda}}$ is a spectral luminosity on the sensor, which is scaled to $Q_{\text {cal }_{\min }}\left[\mathrm{W} / \mathrm{m}^{2} s r \mu m\right]$ 
$L_{\max _{\lambda}}$ is a spectral luminosity on the sensor, which is scaled to $Q_{\text {cal }_{\max }}\left[\mathrm{W} / \mathrm{m}^{2}\right.$ srum $]$;

$M_{L}$ is a rescaling rate;

$A_{L}$ is an additive rescaling rate;

$T_{C}$ is a brightness temperature on the satellite [C];

$K_{1}$ is a channel-dependent thermal conversion constant (Landsat $4 \mathrm{TM}-671.62$, Landsat $5 \mathrm{TM}-607.76$, Landsat 7 ETM +-666.09$)$;

$K_{2}$ is a channel-dependent thermal conversion constant $[\mathrm{K}]$ (Landsat $4 \mathrm{TM}-1284.30$, Landsat $5 \mathrm{TM}-$ 1260.56, Landsat 7 ETM +-1282.71$)$;

$y_{1}$ is an air temperature measured using a satellite image in the vicinity of the Chernivtsi weather station;

$y_{2}$ is an air temperature measured using a satellite image in the vicinity of the Kolomyya weather station;

$y_{3}$ is an air temperature measured using a satellite image in the vicinity of the Vizhnitsa weather station;

$x_{1}$ is a day of observation;

$x_{2}$ is a months of observation;

$x_{3}$ is a year of observation;

$x_{4}$ is a $Y$ coordinate of the location of the meteorological station "Chernivtsi";

$x_{5}$ is a $X$ coordinate of the location of the meteorological station "Chernivtsi";

$x_{6}$ is a height above sea level of observation points in the vicinity of the meteorological station "Chernivtsi";

$x_{7}$ is an air temperature measured by the meteorological station "Chernivtsi";

$x_{8}$ is a cloudiness index measured by a satellite in the vicinity of the Chernivtsi weather station;

$x_{9}$ is a $Y$ coordinate of the "Kolomyya" weather station location; tion

$x_{10}$ is a $X$ coordinate of the "Kolomyya" weather sta-

$x_{11}$ is a height above sea level of observation points in the vicinity of the weather station "Kolomyya";

$x_{12}$ is an air temperature measured by the weather station "Kolomyya";

$x_{13}$ is a cloudiness index measured by a satellite in the vicinity of the weather station "Kolomyya";

$x_{14}$ is a $Y$ coordinate of the location of the weather station "Vizhnitsa";

$x_{15}$ is a $X$ coordinate of the location of the weather station "Vizhnitsa";

$x_{16}$ is a height above sea level of observation points in the vicinity of the weather station "Vizhnitsa";

$x_{17}$ is a air temperature measured by the weather station "Vizhnitsa";

$x_{18}$ is a cloudiness index measured by a satellite in the vicinity of the weather station "Vizhnitsa".

\section{INTRODUCTION}

Information technology monitoring [1] It is built to provide information for decision-making processes in the relevant subject area $[2,3]$. In the process of managing work in hard-to-reach places, monitoring is ordered to (C) Talakh M. V., Holub S. V., Turkin I. B., 2021 DOI 10.15588/1607-3274-2021-2-16 identify external disturbances in the form of changes in weather indicators, in particular air temperature, and their influence on the consequences of decisions made.

Temperature as one of the fundamental climatic markers of the region is utilized to dissect environmental change and establish climate models of various levels [4]. Presently, normal temperature data of the specific region are received, from meteorological stations. Simultaneously, the grid of meteorological stations isn't adequately extended all through the territory of Ukraine. Additionally, as a source of temperature information, thermal imaging of satellites can be utilized to get temperature information for each surface point (accuracy is resolved simply by the goal of room pictures). However, the frequency of thermal imaging isn't regular, and in general, is much lower than the frequency of obtaining data from meteorological stations. In this way, the utilization of space images permits us to consider the spatial component of monitoring, and data from meteorological stations - temporal component, and their combination will permit to create of a complex system of the temperature monitoring of certain territory $[5,6]$.

Simulation by observed data is an essential condition for monitoring since it permits to assess rapidly the current circumstance and foresee their turn of events. Specifically, the effectiveness of the utilization of inductive modeling methods for modeling climatic parameters, one of which is temperature, is demonstrated. Thus, the development of the method for determining the value of air temperature, based on establishing functional dependencies between the investigated parameters is relevant.

The object of study is the processes of environmental monitoring.

The subject of study is the processes of forming an array of input data and the synthesis of climate models in the structure of information technology for environmental monitoring.

The purpose of the study is to reduce information uncertainty in a process of management decisions during the work in uncontrolled territories by expanding the capabilities of information technology for environmental monitoring by developing a new method for modelling air temperature in hard-to-reach places.

\section{PROBLEM STATEMENT}

To reduce information uncertainty in management decision-making, it is proposed to calculate the air temperature at the worksite. A hypothesis was formulated about the existence of a dependence of the air temperature value in the uncontrolled area on the air temperature values measured in the territories, where the air temperature can be measured by meteorological stations. The information content of the indicators and the power of the synthesizer of the monitoring information system will be enough to identify this dependence. The hypothesis is based on knowledge about the emergence of the ecosystem. 
It is necessary to solve the problem of identifying the functional dependence of the air temperature in a given area $Y=\left\{y_{1}, y_{2}, \ldots, y_{m}\right\}$ obtained from the results of processing thermal satellite images with different cloud cover with a given discreteness from the air temperature measured at stationary meteorological stations, form a set $X=\left\{x_{1}, X_{2}, \ldots, X_{n}\right\}$ values, consistent in time:

$$
y_{i}=f\left(x_{1}, x_{2} \ldots . . x_{n}\right), i=\overline{1, m} .
$$

Problem 1 will be considered solved if the built model has the value of the quality criterion no worse than the specified one. To evaluate the models, the absolute error of modeling the temperature values obtained from the results of processing thermal satellite images on the test sequence of observation points of the AID [1]:

$$
A E=R T-P T .
$$

\section{LITERATURE REVIEW}

Presently some studies are demonstrating the effectiveness of using thermal imaging data for estimating and analyzing the air temperature. Specifically, papers $[7,8]$ show a bunch of ways to deal with the determination of air temperature dependent on data received from remote sensors. Frequently, this determination of temperature is done to take care of practical issues [9]. Regularly, time series analysis is utilized to examine the temporal dynamics of temperature. This chance exists since data from most satellites are accessible on normal from the eighties of the last century [10]. Numerous investigations show the utilization of thermal channels for the determination of thermal anomalies in urban areas, plants, or water bodies. A few works show strategies for identifying and foreseeing the distribution of forest fires by thermal imaging of satellites $[11,12]$.

There are various ways to deal with how information can be obtained and handled. Specifically, the examination [13] utilized a model to approximate the annual temperature cycle and acquire periodic parameters to describe annual changes in surface temperature, including average and maximum values, both during daytime and at night.

The effectiveness of utilizing the GMDH for forecasting the value of climatic factors has appeared in numerous studies. Remarkably, the paper [14] shows ways to modeling and predicting average wind speeds per hour. A few investigations offer integrated algorithms to build climatic models. In this manner, the article [15] proposed a technique that was obtained by integrating the kernel principal component analysis method with the locally weighted gathering GMDH, which can be gotten by combining GMDH with the spatial regression and weighted least squares regression. The paper [16] presents another case of the successful utilization of a few algorithms. Specifically, for this situation, GMDH was utilized for establishing a climate model, neural network - for predicting wind speed and power in the short term and wavelet noise decrease - for separating high- frequency emissions in wind speed information, giving a smooth neural network training.

The work [17] proposes the utilization of inductive simulation techniques for the recovery of incomplete or short-term data recorded in the large territory and the making of forecasting climatic models on their basis.

This paper improves the procedure for evaluating the air temperature in hard-to-reach places, utilizing the model of the temperature dependence of the determined by thermal imagery from the temperature got at existing weather stations and creating a monitoring information system.

\section{MATERIALS AND METHODS}

As is known, monitoring is a technology for providing information to decision-making processes $[2,3]$. The necessities for this information technology are determined by the sort of data that the super-system needs for the formation of control actions in managing systems. On account of environmental monitoring, it will be a different level of biological systems, usually - ecosystem. Mainly, the identification of patterns in the temperature regime of the region is significant to foresee conceivable undesirable occasions and to introduce, if necessary, adjustments to economic and other activities. The arrangement of numerous issues related to the investigation of the laws of the temperature system requires the securing, handling, and transformation of large amounts of information - the results of observations. Today, the rules of obtaining and processing various climate characteristics are a remarkably complex process.

The highlights of the climate system present significant limitations on the selection of techniques and tools reasonable for climate prediction. In this manner, the assessment of future environmental change is on a fundamental level possible just as a particular likelihood distribution; along these lines, the undertaking of foreseeing atmosphere is diminished to deciding the probability distribution functions of different attributes of the climate system.

Climate models are attempting to clarify climatic processes with the assistance of fundamental parts of the system - they are simplified versions of reality. The result of these rearrangements is little on a planetary scale; in any case, they are noticeable when foreseeing climate "on the ground". Simultaneously, the worldwide climate can just anticipate general patterns; however, they are not entirely reasonable for practical use. Due to the "gross" spatial resolution, global climate models poorly reproduce the regional climate. Regional models are one of the approaches to explain information as indicated by local highlights of the orography, atmospheric circulation, and so. The use of local models makes it conceivable to distinguish the impacts related to local characteristics of the underlying surface all the more precisely [5-7].

Temperature was chosen as the principal climatic parameter for further work among climatic indicators. The temperature regime list of indicators of the region and the frequency of observations allows showing the state of the 
studied system in the obtained data array. Processing of the results of the observations was done by statistical methods (for pointers of meteorological stations) and classical techniques for geospatial investigation for information acquired by satellite images. Transformation of preparing results into information about the parameters of the temperature system of the area is a mix of the two referenced above strategies. The monitoring results are acquired as two-, three-dimensional conditions. However, the indicators of the temperature system of the territory are controlled by countless variables (principally the dynamics in space and time). The potential outcomes of statistical modeling techniques for showing multifactor impacts are limited [6].

In this case, monitoring information is needed to determine the dependence of temperature values at a certain point in space on a temperature at other points in space, which are characterized by the presence of weather stations. The problem of climate change is currently extremely relevant as in the field of basic research, so far in practice. The development of reliable estimates and objective forecasts of environmental impacts related to climate dynamics determined the researcher's interest in this topic, in particular, the intensity and nature of climate transformations. The task of accurate prediction of temperature values cannot be realized. Therefore, a justified decision of the most significant and informative components accessible for adequate research is required.

The issue explored in this article arises when creating MIS. The proposed arrangement removes the current logical inconsistency between the need to reflect the properties of a complex climate system in the structure of the model and the restricted capacities of the modeling techniques utilized for this. As a result, information about the features of observational objects are not reflected in the model structure and are not used in the decisions making by monitoring results. Consequently, there is a need to develop and implement new techniques for distinguishing and considering these factors, handling and analyzing the received information, which ought to be founded on a combination of exploration results utilizing climatology and meteorology methods joined with current techniques for preparing big data and simulating complex systems. There is a need to reduce the time for receiving conclusions by automating routine work by the widespread use of ITM.

The list of features and their numeric characteristics (contain the results of satellite observations and observations of the air temperature of meteorological stations) form an array of input data (AID) for synthesizing the model of the monitoring object. The input data array is in the form of a two-dimensional table:

Table 1 - The array of observation results

\begin{tabular}{|c|c|c|c|c|}
\hline \multirow{2}{*}{$\begin{array}{c}\text { Dependent } \\
\text { variable }\end{array}$} & \multicolumn{4}{|c|}{ Independent variables } \\
\cline { 2 - 5 } & $x_{1}$ & $x_{2}$ & $\ldots$ & $x_{n}$ \\
\hline$y_{1}$ & $x_{11}$ & $x_{12}$ & $\ldots$ & $x_{1 n}$ \\
\hline$y_{2}$ & $x_{21}$ & $x_{22}$ & $\ldots$ & $x_{2 n}$ \\
\hline$\ldots$ & $\ldots$ & $\ldots$ & $\ldots$ & $\ldots$ \\
\hline$y_{m}$ & $x_{m 1}$ & $x_{m 2}$ & $\ldots$ & $x_{m n}$ \\
\hline
\end{tabular}

(C) Talakh M. V., Holub S. V., Turkin I. B., 2021

DOI 10.15588/1607-3274-2021-2-16
It was proposed to determine the form of the operator $\mathrm{f}$ by decoupling the typical problem of identifying functional dependence with an atypical procedure for synthesizing the MIS model [1]. As a more complex tool for solving the problem of air temperature modeling based on the analyzed data, it was proposed to use inductive modeling methods.

According to the methodology for creating information monitoring technologies [1] in the first stage of the formation of the IMT, the super-system formulates requirements for the content of information that must be obtained from the monitoring results.

That is the reason, that the prerequisite for MIS for this situation is to depict the dependence of temperature values (with specific characteristics of the location, altitude, and the nature of the underlying surface), controlled by space photographs, from the estimations of this indicator at other points determined by meteorological stations and cloudiness.

In the second stage of the IMT formation, the number of levels of information conversion, and the local tasks for each of the levels is determined. For this situation, it is important to form two levels of information transformation. At the first level, the indications of the condition of the climate system are changed over into digital characteristics by the results of observations. Means are estimating instruments for determining the temperature (both directly and with the assistance of thermal photos) and regular maintenance of these processes. At the second level, the information is transformed from the form of the array of numerous characteristics into the form of analytical models, the structure of which reflects the change in temperature values at a certain point of space based on satellite images, from its values at other locations where there is a meteorological station.

First level of monitoring implementation results for the analyzed area during 1985-2016. They are used as components of the initial description of monitoring objects and as variables for the synthesis of second-level models.

$Y$ is a set of the dependent variables (modeled indicators). In this case it is air temperature determined on meteorological stations (48 observation points).

Variables 2-3 are independent variables and form the set $X$.

Here introduced the consequences of studies whose purpose was to decide the idea of the impact of air temperature values determined at meteorological stations and cloudiness index on air temperature, defined by thermal imaging from satellite and meteorological stations. Simultaneously as the examined indicators utilized the estimation of changing it for a particular geographic location.

The study was conducted for three meteorological stations in the Chernivtsi and Ivano-Frankivsk regions (Chernivtsi, Vyzhnytsia, and Kolomyia meteorological stations). Each of the weather stations had 16 observation points. For each weather stations, air temperature was additionally determined from satellite images. As control 
points were used the regions which are remote from the meteorological station, for which it is possible to determine only the temperature by thermal imaging. Since sweeping advancement was to establish the possibility of predicting the territory temperature with no meteorological stations, the temperature was chosen as the dependent variable based on the result of the thermal imaging.

At the third stage of building the ITM, the structure of its information transformation subsystem is formed. The method of ascending model synthesis and tools of MIS was used. Under the given dependent and independent variables, models are synthesized at each level of information transformation; models of a separate level are combined into executions. The output signals of the models of the lower penalty form arrays of initial data for the synthesis of the models of the upper penalty $[18,19]$ For the integration of models of the second level of information conversion of the MIS temperature based on the satellite of the material stations, a multi-row GMDH algorithm was used [3]. In the process of synthesizing the model, data obtained during 1985-2017 were used for the territory of the weather station. For testing the model, we used the results of observations obtained during the same period for the lands where there are no meteorological stations.

The informativeness of the indicators, which form the array of input data, determines the ITM's ability to perform the monitoring task. The value of independent variables (Table 1) was obtained as observations from meteorological stations in a suitable form for the forming of the AID. The results of satellite observations, which were used to form the dependent variables of modeling, are not suitable for use in the AID without conversion. Their transformation is required.

To download satellite images and save them in a temporary folder, the API service of the American Geological Research Center glovis.usgs.gov was used [20]. API of two weather services were used simultaneously worldweatheronline.com and rp5.ua. The first service allows to get the coordinates of weather stations, and the second is used to get temperature data. It's possible, because, each pixel besides attribute values, also has geographic coordinates, so analyzing each pixel sequentially, the system sends requests to weather servers for the same period for satellites and weather stations [21, 22]. Data were automatically downloaded in the vicinity of weather stations. These data characterize each of the observation points at different observation times during the study period. The satellites of the Landsat series of series 4, 5, $7,8[20,23]$, namely, their thermal channels (the specific channel number depends on the series). The choice of satellites is due to the presence of a thermal infrared sensor image $(10.4-12.5 \mu \mathrm{m})$. Data from the Landsat series satellites have been presented since 1982 and are freely available.

Each scene is read by pixel (an image concerning a particular date, which has a set of specific characteristics that are contained in a file with metadata). A special method has been developed to implement this process. (C) Talakh M. V., Holub S. V., Turkin I. B., 2021 DOI 10.15588/1607-3274-2021-2-16
As a result, this method returns an object containing already processed (converted to surface temperature) pixel values.

The conversion of the attributive values of thermal channels pixels of space images into the temperature value takes place in several stages. The first is the definition of radiant luminosity. For Landsat satellites of series 4,5 , and 7 , the radiant luminosity on the satellite is calculated by the expression:

$$
L_{\lambda}=\left(\frac{L_{\max _{\lambda}}-L_{\min _{\lambda}}}{Q_{c a l_{\text {max }}}-Q_{c a l_{\text {min }}}}\right)\left(Q_{c a l}-Q_{c a l_{\text {min }}}\right)+L_{\min _{\lambda}} .
$$

For Landsat 8 , the satellite radiant luminosity is calculated using the formula (4):

$$
L_{\lambda}=M_{L} Q_{\text {cal }}+A_{L}
$$

At the second stage, the obtained results are recalculated into absolute dimensionless values of reflectivity, which characterizes the ratio of light reflected by the surface and the light entering it. Unlike luminosity, which significantly depends on the lighting conditions, the vividness is its own relatively unchanged characteristic of the object of observation [24]. This exact value was used as the temperature determined from space images.

To calculate the temperature on the satellite for the Landsat series 4, 5, and 7, the following expression was used:

$$
T_{C}=\frac{K_{2}}{\ln \left(K_{1} / L_{\lambda}+1\right)}-273.15
$$

For the Landsat 8, and $K_{1}$ values are given in the image metafile. The values obtained from the metadata are converted from Kelvin to Celsius values.

Temperature data from meteorological stations were received from meteorological servers [21, 22]. Terrestrial meteorological stations are used to evaluate the reliability of temperature measurements from remote sensing data for Landsat satellites.

Since spatial data were obtained from different sources, they were in different cartographic projections. For unification, all data were transformed into a ITM projection, in which all the coordinates given in the the work are presented.

The main disadvantage of this approach is the effect of changes in the shadows and illumination of the earth's surface, vegetation, and objects when analyzing satellite images limits the use of the space-time approach. However, the development of a method for modeling, detecting, and removing shadows on images allows, after additional processing, to carry out the comparison of multitime images.

To compare the values of temperature measurements, according to the data of meteorological stations and the results of the thermal band from satellite images, we se- 
lected images from the Landsat $-4,-5,-7$, and -8 satellites.

As a result of converting every image to matrix (with attribute values of pixels) we obtain digital data that do not have physical dimensions. It is necessary to convert the space data to the real temperature value. All the required information about the input data is contained in the metadata file supplied with each image (scene).

All input images have resolution $30 \mathrm{~m}$ per pixel and are sufficiently accurate to predict climate indicators. When comparing meteorological and satellite data, the concept of the effective forecast radius of a meteorological station (the experimentally established territory for which the proper temperature can be measured at the meteorological station) was used. It is known that on average, such a radius is about $30 \mathrm{~km}$. In this case, 16 points from satellite images closest to the weather station were used to restore weather data.

Also, a significant aspect that was considered during arranging an experiment was the frequency of data acquisition. The fixation of temperature indicators at meteorological stations occurs several times a day (from 4 to 12 times, depending on the type of meteorological station). However, fully satisfying the time component of the weather station research is almost devoid of spatial (in case of working with many stations model would not still be regional). Simultaneously, another source of input data, in particular, satellite images, is completely good in the spatial component of the analysis; however, the Landsat satellite captures 16-18 days, that is, the time during which the satellite turns around the Earth and how often it records. Also, the cloudiness value of more than $50 \%$ makes it almost impossible to use a specific scene to an image, which further reduces the frequency of data acquisition. So, one of the tasks of creating IMT within this research was to develop the methods for the common use of all these types of input data.

Primary analysis of the initial data array shows that the graphs of the course of temperatures obtained by both methods are almost identical, which suggests the expediency of using this approach in the future. However, absolute values at specific points are different, which may depend on diversity of factors. Especially, cloudiness, that was considered in the model. Moreover, also from the type of underlying surface that affects the temperature determined by the image, while in the meteorological stations the temperature indicators are measured at a level of $2.6 \mathrm{~m}$ above the surface of the earth.

\section{EXPERIMENTS}

To solve problem 1, the temperature values were determined from satellite images in the vicinity of meteorological stations in Chernivtsi, Kolomyia, and Vyzhnytsya. After that, the values of air temperatures in these territories were compared with the values of these indicators measured by meteorological stations, and an array of input data was formed in the form of Table 1. The models were built in the form of the dependence of the air temperature determined from satellite images in the area (C) Talakh M. V., Holub S. V., Turkin I. B., 2021 DOI 10.15588/1607-3274-2021-2-16 of one of the three meteorological stations on the air temperature measured by the other two weather stations.

The list of indicators that are used as elements of the set of independent $\mathrm{X}$ and dependent variables $\mathrm{Y}$ are presented in nomenclature.

Since the air temperature in the uncontrolled territories had to be calculated without data received from the satellite, the cloudiness indicators, denoted by the variables $x_{8}, x_{13}, x_{18}$, were removed from the array of input data. Therefore, the problem of interpreting the functional dependencies of individual elements of the set $Y$ on certain elements of the set $\mathrm{X}$ was solved according to the expressions:

$$
\begin{aligned}
& y_{1}=f\left(x_{1}, x_{2}, x_{3}, x_{4}, x_{5}, x_{6}, x_{9}, x_{10}, x_{11}, x_{12}, x_{14}, x_{15}, x_{16}, x_{17}\right) ;(6) \\
& y_{2}=f\left(x_{1}, x_{2}, x_{3}, x_{4}, x_{5}, x_{6}, x_{7}, x_{9}, x_{10}, x_{11}, x_{14}, x_{15}, x_{16}, x_{17}\right) ;(7) \\
& y_{3}=f\left(x_{1}, x_{2}, x_{3}, x_{4}, x_{5}, x_{6}, x_{7}, x_{9}, x_{10}, x_{11}, x_{12}, x_{14}, x_{15}, x_{16}\right) \cdot(8)
\end{aligned}
$$

Thus, expression (6) reflects the dependence of the value $y_{1}$ of the air temperature measured by the satellite in the area of the Chernivtsi meteorological station on the characteristics of observation points and on the results of measurements by the Kolomyya and Vizhnitsa meteorological stations $x_{9}-x_{17}$. Expression (7) reflects the dependence of the value $y_{2}$ of the air temperature measured by the satellite in the area of the Kolomyya meteorological station on the characteristics of observation points and the measurement results by the Chernivtsi and Vizhnitsa meteorological stations $x_{4}-x_{7}, x_{14}-x_{17}$. Expression (8) reflects the dependence of the value $y_{2}$ of the air temperature measured by the satellite in the area of the Vizhnitsa meteorological station on the characteristics of observation points and the results of measurements by the Chernivtsi and Kolomyya meteorological stations $x_{4}-x_{7}, x_{9}-x_{12}$.

To solve problems (6), (7), (8), the multi-row GMDH algorithm was used [18]. The array of input data was formed based on the results of simultaneous observations of 16 points around each of the 3 meteorological stations and the transformation of satellite images obtained during 1985 - 2016. Data for 14 indicators of the set X were obtained from the results of 928 measurements of air temperature at 3 meteorological stations, to obtain indicators of the set $\mathrm{Y}$ were processed 58 satellite images. That is, according to Table 1 , the values $m=928, n=14$.

To build the model, observation points were used, built using 57 satellite images. 16 observation points, formed from the results of measurements of 16 observation points around the meteorological stations using the last 58th satellite image, used as a test data set. They were not used in the process of building the model.

\section{RESULTS}

Figure 1 shows the values of the absolute errors of modeling the air temperature on the test data set. 


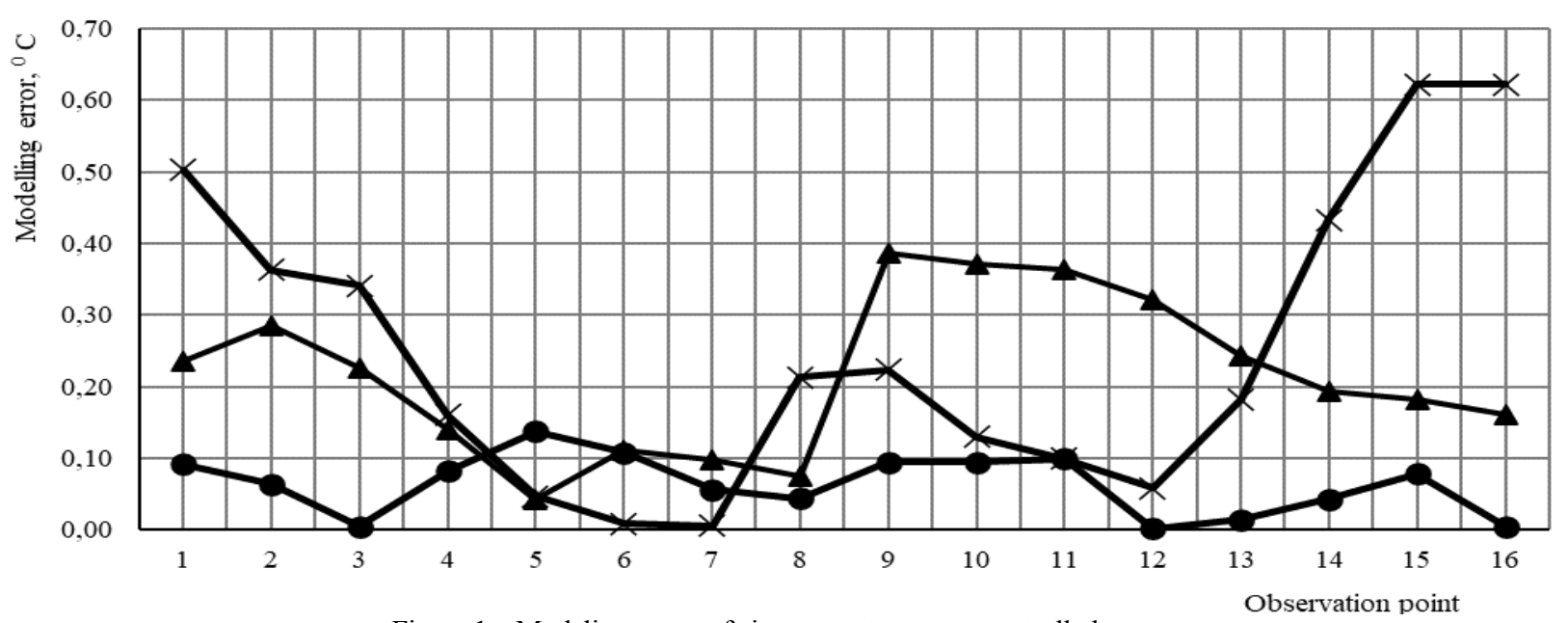

Figure 1 - Modeling errors of air temperature on uncontrolled areas:

- Chernivtsi, $\Delta$ - Kolomyya, $x$-Vizhnitsa

\section{DISCUSSION}

It should be noted that the models were tested on data, that did not take part in their creation, so obtained the results reflect the persistence of the model. Such a choice of parameters for modeling and generating an array of input data is determined by the need to avoid multicollinearity to the consistency of two or more variables in the models.

Modeling error, calculated by expression (2), varied in the range from $0.02 \%$ to $7.82 \%$, which did not exceed $0.7^{\circ} \mathrm{C}$. at separate observation points. And in this case:

- modelling error, reflecting dependence (6), varies in the range $(0.02-1.25) \%$, which does not exceed $0.2^{\circ} \mathrm{C}$, the standard deviation is $0,05^{\circ} \mathrm{C}$;

- modelling error, reflecting dependence (7), varies in the range $(0.54-5.13) \%$, which does not exceed $0.4^{\circ} \mathrm{C}$, the standard deviation is $0.17^{\circ} \mathrm{C}$;

- modelling error, reflecting dependence (8), varies in the range $(0.06-7.82) \%$, which does not exceed $0.7^{\circ} \mathrm{C}$, the standard deviation of the simulation results is $0.21^{\circ} \mathrm{C}$.

The general characteristics of the models, considered (Fig. 1), confirms that the characteristics of the simulation results depend on the distance between the plotted points and the comparison of their absolute heights. Comparing the models, it was found that the difference in indicators (longitude, latitude, and altitude) between the modeled point and the variable, which showed a change in the function direction at about the same level. This suggests that for each point for which the temperature simulation is carried out, the point(s) can be set that has the most significant effect on the obtained value.

The study of existing climatic models of various levels allows us to assert that the temperature depends more on its dynamics in space and time. So, during the processing of space images, the date, as well as the specific shooting season, is essential. This is taken into account when carrying out an atmospheric correction and is one of the necessary procedures for preparing the analyzed data [9].

The use of thermal satellite images to predict temperature is also important because they contain information about cloudiness, as well as the location of the studied points and even heights, which is also one of the decisive factors influ-

(C) Talakh M. V., Holub S. V., Turkin I. B., 202

DOI $10.15588 / 1607-3274-2021-2-16$ encing the obtained value. Also, the type of underlying surface is taken into account on satellite images and has a noticeable effect on the temperature regime [9].

An analysis of the results obtained shows that the synthesized MIS models are accurate and adequate since the difference between the air temperature values calculated by the models and their actual values measured at meteorological stations, and the value of the standard deviation of the simulation results from the actual values are acceptable. Even though the accuracy and adequacy of the simulation results were evaluated on test data sets, the obtained models are stable.

Thus, the hypothesis about the possibility of calculating the air temperature value in the uncontrolled territory by monitoring information systems using the results of measurements of operating meteorological stations was obtained experimentally. The possibility of identifying functional dependencies of air temperature in remote areas on the available indicators has been proved.

Obtained results make it possible to substantiate the possibility of obtaining climatic characteristics of remote areas by identifying their dependences on the results of measurements at active meteorological stations, which are difficult to access or uncontrollable.

\section{CONCLUSIONS}

The problem of identification of the functional dependence of air temperature in uncontrolled places on the results of observations at meteorological stations is solved. The results obtained were used in the process of creating a new method of climate modeling within ITCM. Experimental confirmation of the hypothesis about the possibility of using satellite images in regional models of temperature prediction has been obtained. The effectiveness of the application of the methodology for the creation of information technologies for monitoring in the implementation of the tasks of reducing uncertainty in making decisions on the management of works in uncontrolled territories has been proved.

The analysis and synthesis of existing approaches, methods, and means of temperature prediction, including by satellite imagery, in particular, by thermal imaging, has been carried out. It was revealed that the most effective means of 
solving the problem is the use of methods of inductive modeling.

The analysis and synthesis of existing approaches, methods, and means of temperature prediction, including by satellite imagery, in particular, by thermal imaging, has been carried out. It was revealed that the most effective means of solving the problem is the use methods of inductive modeling.

During the investigation of the variables' selection of the input data array, it was shown that satellite imagery data could be used in regional models of temperature prediction, and temperature traces obtained from satellite imagery and weather stations at similar points show similar dynamics.

The effectiveness of GMDH using of the multi-row algorithm for forecasting temperature for areas with no meteorological stations is shown.

The scientific novelty of obtained results is the improvement of the methodology for creating information technologies for multilevel monitoring by using the existing method of adaptive synthesis of models to solve the new problem of creating a new method of climate modeling. In contrast to the existing ones, the method combines the processes of satellite observations and observations of the climate on the soil surface, taking into account the spatial and temporal characteristics, to form an array of input data (AID), with the processes of synthesis of models of monitoring information systems (MIS) [1] and the processes of forming multi-level model structures MIS for converting observation results, and with the rules for interpreting the results obtained for calculating the temperature value in uncontrolled territories. This makes it possible to expand the capabilities of monitoring information systems to perform new tasks of calculating air temperature values in uncontrolled areas during the time between space observations.

The practical significance of the obtained results is in the possibility of constructing an information monitoring system that ensures a continuous determination of air temperature in areas where there are no meteorological stations. The results can be widely used to reduce the uncertainty of decisionmaking processes while eliminating both global and local problems. In particular, for planning work in hard-to-reach and uncontrolled territories, observing climate changes and creating climate models, or identifying the state of vegetation and the presence of traces of human activity in the studied territories.

Prospects for further research are to improve developed monitoring information system due to the use of a complex mechanism is needed that combines OLAP technology and IoT search mechanisms, which will affect the final result, for example, taking into account the features of the underlying surface or the presence of "heat islands" over cities.

\section{REFERENCES}

1. Golub S. V. Multilevel modelling in environmental monitoring technologies: monograph. Cherkasy, Ed. from. ChNU named after Bohdan Khmelnitsky, 2007, 220 p. ISBN 978-966-353-062-8.

2. Kunytska S., Holub S. Eds: Palagin A., Anisimov A., Morozov A., Shkarlet S. Multi-agent Monitoring Information Systems, Mathematical Modeling and Simulation of Systems. MODS. Advances in Intelligent Systems and Computing. Cham, Springer, 2020, Vol. 1019, pp. 164-171. DOI: 10.1007/978-3-030-25741-5_17

(C) Talakh M. V., Holub S. V., Turkin I. B., 2021

DOI 10.15588/1607-3274-2021-2-16
3. Holub S., Burliai I. The accuracy improving modelling of firefighting process in the Information system of fire safety monitoring, Journal of the Technical University of Gabrovo, 2014, Vol. 47, pp. 13-16. http://izvestia.tugab.bg/index.php?m=20\&tom=5.

4. Bathiany S., Dakos V., Scheffer M., Lenton T. M. Climate models predict increasing temperature variability in poor countries, Science Advances, 2018, Vol. 4, Issue 5, pp. 1-10. DOI: 10.1126/sciadv.aar5809

5. Rosselló J. C., Poyatos R., Ninyerola M., Llorens P. Combining remote sensing and GIS climate modelling to estimate daily forest evapotranspiration in a Mediterranean mountain area, Hydrology and Earth System Sciences, 2011, Vol. 15, Issue. 5, pp. 1563-1575. DOI:10.5194/hess-15-1563-2011.

6. Yang J. Fu R., Gong P., Zhang M. The role of satellite remote sensing in climate change studies, Nature Climate Change, 2013, Vol. 3 , Issue 1, pp. 875-883. DOI:10.1038/nclimate1908.

7. Niclos R., Valiente J. A., Barbera M. J., Caselles V. Land Surface Air Temperature Retrieval From EOS-MODIS Images, IEEE Geoscience and Remote Sensing Letters, 2014, Vol. 11, No. 8, pp. 1380-1384. DOI: 10.1109/LGRS.2013.2293540.

8. Converting Landsat TM and ETM+ thermal bands to temperature, The Yale Center for Earth Observation, 2010, Online]. Available: http:/geography.middlebury.edu/data/gg1002/Handouts/Landsat_D N_Temp.pdf.

9. Meaden G. J., Aguilar-Manjarrez J. Advances in geographic information systems and remote sensing for fisheries and aquaculture FAO Fisheries and Aquaculture Technical Paper, 2013, No. 552, 425 p. ISBN 978-92-5-107391-9

10. Merchant C. J., Embury O., Bulgin C. E., et al. Satellite-based timeseries of sea-surface temperature since 1981 for climate applications, Sci Data, 2019, Vol. 6, Issue 223, pp. 1-18. [Online]. Available: https:/www.nature.com/articles/s41597-019-0236-X. DOI: 10.1038 / s41597-019-0236-x

11. Heyerdahl E. K., McKenzie D., Daniels L. D., Hessl A. E., Littell J. S., Mantua N. J. Climate drivers of regionally synchronous fires in the inland Northwest, International Journal of Wildland Fire, 2008, Vol. 17, pp. 40-49. DOI:10.1071/WF07024

12. Sundara Kumar K., Udayabhaskar P., Padmakumari K. Esti-mation of Land surface temperature to study Urban Heat Island Effect Using Landsat ETM+ image, International journal of engineering, science and technology, 2018, Vol. 4, Issue 2, pp. 807-814. ISSN : 0975-5462

13. Zhao Wei An, Juelin He, Yanhong Wu, Donghong Xiong, Fengping Wen, Ainong Li An Analysis of Land Surface Temperature Trends in the Central Himalayan Region Based on MODIS Products, Remote Sensing, 2019, Vol. 11(8): 900, pp. 1-24. [Online]. Available: https://www.mdpi.com/2072-4292/11/8/900 DOI: $10.3390 / \mathrm{rs} 11080900$

14. Abdel-Aal R. E., Elhadidy M.A., Shaahid S. M. Modeling and forecasting the mean hourly wind speed time series using GMDH-based abductive networks, Renewable Energy, 2009, Vol. 34, Issue 7, pp. 1686-1699. DOI: 10.1016/j.renene.2009.01.001.

15. Elattar E., Taha I. B M An Advanced Intelligent Method for Wind Power Prediction, International Journal of Scientific and Engineering Research, 2013, Vol. 5, pp. 1-10. Available: https://www.researchgate.net/profile/Ibrahim-Taha10/publication/292995732_An_Advanced_Intelligent_Method_for Wind Power Prediction/links/56b4fc6708ae44bb3305798b/AnAdvanced-Intelligent-Method-for-Wind-Power-Prediction.pdf

16. Makhloufi S. Wind Speed and Wind Power Forecasting Using Wavelet Denoising-GMDH Neural Network, The 5th International Conference on Electrical Engineering, November 6-7. Algiers, Algeria, 2018, pp. 29-31. DOI: 10.1109 / GTDAsia.2019.8715985.

17. Saghafian B., Ghasemi S., Nasseri M. Backcasting long-term climate data: evaluation of hypothesis, Theoretical and Applied Climatology, 2017, Volume 132, Issue 3-4, pp. 717-726, DOI:10.1029/2010WR009104.

18. Madala H. R., Ivakhnenko A. G. Inductive Learning Algorithms for Complex System Modeling. Boca Raton; Ann Arbor; London; Tokyo: CRC Press, 1994, 368 p. ISBN 9781315894393.

19. Müller, J.-A., Lemke, F. Self-Organising Data Mining. Hamburg, Libri, 2000, 250 p. U.S. Geological Survey [Electronic resource]. Access mode: https://www.usgs.gov/. DOI 10.1080/0232929031000136135. 
20. USGS [Electronic resource]. Access mode: https://www.usgs.gov/.]

21. RP5 [Electronic resource]. Access mode: http://rp5.ua.

22. Worldweather [Electronic resource]. Access mode: https://www.worldweatheronline.com.

23. NASA. Landsat Science [Electronic resource]. Access mode: http://landsat.gsfc. nasa.gov.
24. Zabelin S. A., Tulegulov A. D. Metodika atmosfernoy korrektsi snimkov Landsat [Tekst], Bulletin ENU named by. L. N. Gumileva, 2011, No. 6, pp. 147-154. ISSN 2616-6771.

Received 23.12.2020. Accepted 25.04.2021.

УДК 504.064.37: 004.942

\section{ІНФОРМАЦІЙНА ТЕХНОЛОГІЯ КЛІМАТИЧНОГО МОНТТОРИНГУ}

Талах М. В. - канд. біол. наук, асистент кафедри комп’ютерних наук Чернівецького національного університету ім. Юрія Федьковича, Чернівці, Україна.

Голуб С. В. - д-р техн. наук, професор кафедри програмного забезпечення автоматизованої системи Черкаського державного технологічного університету, Черкаський державний технологічний університет, Черкаси, Україна.

Туркін І. Б. - д-р техн. наук, професор, завідувач кафедри інженерії програмного забезпечення Національного аерокосмічного університету «Харківський авіаційний інститут», Харків, Україна

\section{АНОТАЦІЯ}

Актуальність. Для зниження інформаційної невизначеності про закономірності зміни температури повітря при управлінні роботами у важкодоступних місцях використовується інформаційна технології моніторингу [1]. Виконувалось завдання створення методу моделювання одного із кліматичних показників, температури повітря, на заданих територіях в структурі інформаційної технології моніторингу. Кліматичні моделі $є$ основними інструментами для дослідження реакції екологічної системи на зовнішні та внутрішні впливи. Проблема зниження інформаційної невизначеності при прийнятті управлінських рішень усувається шляхом прогнозування наслідків застосування запланованих керуючих впливів за допомогою використання в інформаційній технології моніторингу методів кліматичного моделювання. В інформаційну технологію кліматичного моніторингу поєднані методи супутникових спостережень $i$ спостережень за кліматом на поверхні грунту з урахуванням просторово-часових характеристик, для формування масиву вхідних даних, із методами синтезу моделей моніторингових інформаційних систем [1] і методами формування багаторівневих модельних структур моніторингових інформаційних систем [1] для перетворення результатів спостережень у знання, та із правилами інтерпретації отриманих результатів для розрахунку значення температури на непідконтрольних територіях.

Мета роботи полягає в розв'язанні задачі ідентифікації функціональної залежності температури повітря на заданій непідконтрольній території від результатів спостережень за характеристиками клімату метеорологічними станціями на поверхні грунту в структурі інформаційної технології кліматичного моніторингу.

Метод. Удосконалено методологію створення інформаційних технологій моніторингу з метою розширення ії можливостей для виконання нових завдань прогнозування температури за допомогою даних тепловізійних супутників та метеостанцій шляхом використання нового методу кліматичного моделювання. Застосовувався системний підхід до процесу кліматичного моделювання, метод групового урахування аргументів для розв'язання задач ідентифікації функціональної залежності, методи математичної статистики для оцінки моделей.

Результати. Відхилення розрахованих значень температури за синтезованими моделями МІС від дійсних значень, отриманих за результатами спостережень штучними супутниками Землі у середньому не перевищує $2,5^{\circ} \mathrm{C}$. Сліди температури, отримані від супутникових зображень та метеорологічних станцій у подібних точках, мають схожу динаміку.

Висновки. Розв'язана задача ідентифікації функціональної залежності температури повітря у непідконтрольних місцях від результатів спостережень на метеорологічних станціях. Отримані результати використані в процесі створення нового методу кліматичного моделювання в межах інформаційної технології кліматичного моніторингу. Отримано експериментальне підтвердження гіпотези про можливість використання супутникових зображень в регіональних моделях прогнозування температури. Доведена ефективність застосування методології створення інформаційних технологій моніторингу при виконанні завдань зниження невизначеності при прийнятті рішень із управління роботами на непідконтрольних територіях.

КЛЮЧОВІ СЛОВА: інформаційна технологія, моніторинг, кліматичні моделі, спостереження, температура повітря, тепловізори, супутники Landsat, індуктивне моделювання, машинне навчання.

\section{УДК 504.064.37: 004.942}

\section{ИНФОРМАЦИОННАЯ ТЕХНОЛОГИЯ КЛИМАТИЧЕСКОГО МОНИТОРИНГА}

Талах М. В. - канд. биол. наук, ассистент кафедры компьютерных наук Черновицкого национального университета им. Юрия Федьковича, Черновцы, Украина

Голуб С. В. - д-р техн. наук, профессор кафедры программного обеспечения автоматизированных систем Черкасского государственного технологического университета, Черкассы, Украина.

Туркин И. Б. - д-р техн. наук, профессор, заведующий кафедрой инженерии программного обеспечения Национального аэрокосмического университета «Харьковский авиационный институт», Харьков, Украина.

\section{АННОТАЦИЯ}

Актуальность. Для снижения информационной неопределенности о закономерности изменения температуры воздуха при управлении работами в труднодоступных местах используется информационная технологии мониторинга [1]. Выполнялось задача создания метода моделирования одного из климатических показателей, температуры воздуха, на заданных территориях в структуре информационная технологии мониторинга. Климатические модели являются основными инструментами для исследования реакции экологической системы на внешние и внутренние воздействия. Присоединился Проблема снижения информационной неопределенности при принятии управленческих решений устраняется путем прогнозирования последствий применения запланированных управляющих воздействий с помощью использования в информационной технологии мониторинга методов климатического моделирования. В информационную технологию климатического мониторинга объединены методы спутниковых наблюдений и наблюдений за климатом на поверхности почвы с учетом пространственно-временных характеристик, для формирования массива входных данных массива входных данных, с методами синтеза моделей мониторинговых информационных систем [1] и методами формирования многоуровневых модель- 
ных структур мониторинговых информационных систем [1] для преобразования результатов наблюдений в знания, и с правилами интерпретации полученных результатов для расчета значения температуры на неподконтрольных территориях.

Цель работы заключается в решении задачи идентификации функциональной зависимости температуры воздуха на заданном неподконтрольной территории от результатов наблюдений за характеристиками климата метеорологическими станциями на поверхности почвы в структуре информационная технологии мониторинга.

Метод. Усовершенствована методология создания информационных технологий мониторинга с целью расширения ее возможностей для выполнения новых задач прогнозирования температуры с помощью данных тепловизионных спутников и метеостанций путем использования нового метода климатического моделирования. Применялся системный подход к процессу климатического моделирования, метод группового учета аргументов для решения задач идентификации функциональной зависимости, методы математической статистики для оценки моделей.

Результаты. Отклонение рассчитанных значений температуры с синтезированными моделями МИС от действительных значений, полученных по результатам наблюдений искусственными спутниками Земли в среднем, не превышает $2,5^{\circ} \mathrm{C}$. Следы температуры, полученные от спутниковых изображений и метеорологических станций в подобных точках, имеют похожую динамику.

Выводы. Решена задача идентификации функциональной зависимости температуры воздуха в неподконтрольных местах от результатов наблюдений на метеорологических станциях. Полученные результаты использованы в процессе создания нового метода климатического моделирования в пределах информационной технологии мониторинга. Получено экспериментальное подтверждение гипотезы о возможности использования спутниковых изображений в региональных моделях прогнозирования температуры. Доказана эффективность применения методологии создания информационных технологий мониторинга при выполнении задач снижения неопределенности при принятии решений по управлению работами на неподконтрольных территориях.

КЛЮЧЕВЫЕ СЛОВА: информационная технология, мониторинг, климатические модели, наблюдения, температура воздуха, тепловизоры, спутники Landsat, индуктивное моделирование, машинное обучение.

\section{ЛІТЕРАТУРА / ЛИТЕРАТУРА}

1. Голуб С. В. Багаторівневе моделювання в технологіях моніторингу оточуючого середовища. Черкаси : Вид. від. ЧНУ імені Богдана Хмельницького, 2007. - 220 с. ISBN 978-966-353$062-8$

2. Kunytska S. Multi-agent Monitoring Information Systems S. Kunytska, S. Holub // Mathematical Modeling and Simulation of Systems. MODS. Advances in Intelligent Systems and Computing / Eds: A. Palagin, A. Anisimov, A. Morozov, Shkarlet S. - Cham Springer, 2020. - Vol 1019. - P. 164-171. DOI: 10.1007/978-3-03025741-5 17

3. Holub $\mathrm{S}$. The accuracy improving modelling of firefighting process in the Information system of fire safety monitoring / S. Holub, I. Burliai // Journal of the Technical University of Gabrovo. - 2014. - Vol. 47. P. $13-16$.

https://www.academia.edu/10082252/The accuracy improving of m odel-

ling_of_firefighting_process_in_the_information_system_of_fire_safe ty monitoring

4. Climate models predict increasing temperature variability in poor countries / [S. Bathiany, V. Dakos, M. Scheffer, T. M. Lenton] // Science Advances. - 2018. - Vol. 4, Issue 5. - P. 1-10.

5. Combining remote sensing and GIS climate modelling to estimate daily forest evapotranspiration in a Mediterranean mountain area [J. C. Rosselló, R. Poyatos, M. Ninyerola. P. Llorens] // Hydrology and Earth System Sciences. - 2011. - Vol. 15, Issue 5. - P. 1563 1575. DOI: $10.5194 /$ hess-15-1563-2011.

6. The role of satellite remote sensing in climate change studies / [J Yang, R. Fu, P. Gong, M. Zhang] // Nature Climate Change. - 2013. Vol. 3, Issue 1. - P. 875-883. DOI:10.1038/nclimate1908.

7. Land Surface Air Temperature Retrieval From EOS-MODIS Images / [R. Niclos, J. A. Valiente, M. J. Barbera, V. Caselles] // IEEE Geoscience and Remote Sensing Letters. - 2014. - Vol. 11, No. 8. P. 1380-1384. DOI: 10.1109/LGRS.2013.2293540.

8. Converting Landsat TM and ETM+ thermal bands to temperature The Yale Center for Earth Observation. - 2010, Online]. Available: http:/geography.middlebury.edu/data/gg1002/Handouts/Landsat DN Temp.pdf.

9. Meaden G. J. Advances in geographic information systems and remote sensing for fisheries and aquaculture / G. J. Meaden, J. AguilarManjarrez // FAO Fisheries and Aquaculture Technical Paper. - 2013. - No. 552. - 425 p. ISBN 978-92-5-107391-9

10. Merchant C. J. Satellite-based time-series of sea-surface temperature since 1981 for climate applications / [C. J. Merchant, O. Embury, C. E. Bulgin et al.] // Sci Data. - 2019. - Vol. 6, Issue 223. - P. 1-18 [Online]. Available: https://www.nature.com/articles/s41597-0190236-x. DOI: 10.1038 / s41597-019-0236-x.

11. Climate drivers of regionally synchronous fires in the inland Northwest / [E. K. Heyerdahl, D. McKenzie, L. D. Daniels et al.] // Interna-

(C) Talakh M. V., Holub S. V., Turkin I. B., 2021

DOI 10.15588/1607-3274-2021-2-16 tional Journal of Wildland Fire. - 2008. - Vol. 17. - P. 40-49. DOI:10.1071/WF07024.

12. Sundara Kumar K. Esti-mation of Land surface temperature to study Urban Heat Island effect Using Landsat ETM+ image / K. Sundara Kumar, P. Udayabhaskar, K. Padmakumari // International journal of engineering, science and technology. - 2018. - Vol. 4, Issue 2. P. 807-814. ISSN : 0975-5462.

13. Zhao Wei An Analysis of Land Surface Temperature Trends in the Central Himalayan Region Based on MODIS Products / Wei Zhao, Juelin He, Yanhong $\mathrm{Wu}$ et al] // Remote Sensing. - 2019. Vol. 11(8): 900. - P. 1-24. [Online]. Available: https://www.mdpi.com/2072-4292/11/8/900. DOI: $10.3390 / \mathrm{rs} 11080900$

14. Abdel-Aal R. E. Modeling and forecasting the mean hourly wind speed time series using GMDH-based abductive networks / R. E. Abdel-Aal, M. A. Elhadidy, S. M. Shaahid // Renewable Energy. 2009. - Vol. 34, Issue 7. - P. 1686-1699. DOI: $10.1016 /$ j.renene.2009.01.001.

15. Elattar E. An Advanced Intelligent Method for Wind Power Prediction / E Elattar, I. B M Taha // International Journal of Scientific and Engineering Research. - 2013. - Vol. 5. - P. 1-10. Available: https://www.researchgate.net/profile/Ibrahim-Taha10/publication/292995732_An_Advanced_Intelligent_Method_for_W ind Power Prediction/links/56b4fc6708ae44bb3305798b/AnAdvanced-Intelligent-Method-for-Wind-Power-Prediction.pdf

16. Makhloufi S. Wind Speed and Wind Power Forecasting Using Wavelet Denoising-GMDH Neural Network / S. Makhloufi // The 5th International Conference on Electrical Engineering, November 6-7. Algiers, Algeria : 2018. - P. 29-31. DOI: 10.1109 GTDAsia.2019.8715985.

17. Saghafian B. Backcasting long-term climate data: evaluation of hypothesis / B. Saghafian, S. Ghasemi, M. Nasseri // Theoretical and Applied Climatology. - 2017. - Volume 132, Issue 3-4. - P. 717 726, 2017. Doi:10.1029/2010WR009104.

18. Madala H. R. Inductive Learning Algorithms for Complex System Modeling / H. R. Madala, A. G. Ivakhnenko. - Boca Raton; Ann Arbor; London; Tokyo: CRC Press, 1994. - 368 p. ISBN 9781315894393

19. Müller J.-A. Self-Organising Data Mining / J.-A. Müller, F. Lemke. Hamburg : Libri, 2000. $\quad-\quad 250$ p DOI:10.1080/0232929031000136135.

20. Геологічний сервіс. USGS [Електронний ресурс]. - Режим доступу: https://www.usgs.gov/.].

21. RP5 [Електронний ресурс]. - Режим доступу: http://rp5.ua.

22. Worldweather [Електронний ресурс]. - Режим доступу: https://www.worldweatheronline.com.

23. NASA. Landsat Science [Електронний ресурс]. - Режим доступу: http://landsat.gsfc. nasa.gov

24. Забелин С. А. Методика атмосферной коррекции снимков Landsat [Текст] / С. А. Забелин, А. Д. Тулегулов // Вестник ЕНУ им. Л. Н. Гумилева. - 2011. - № 6. - С. 147-154. ISSN 2616-6771. 